\title{
The Role of Demographic Policies in the Internationalization of Romanian Higher Education
}

\author{
Robert Santa and Cezar Mihai Haj
}

\section{Introduction}

In recent years, several European countries have tuned their policies pertaining to international students to their need for immigration reform and the recruitment of highly skilled, highly educated professionals into their economies. Europe has been lagging behind other developed regions when it comes to attracting highly educated labour from abroad, despite being one of the regions with the steepest demographic downturns in the world. Governments have been trying to correct this either by making it easier for highly skilled immigrants to move to Europe (via a multitude of schemes such as the EU-backed 'Blue Card') or by allowing international graduates to become long-term residents in an expedited fashion.

A growing shortage of skilled workers and the role of higher education in tackling this issue have also been emerging as an important topic in the Romanian public debate, and immigration legislation has been revised and tuned to European practices. This paper aims to analyse the implementation of recent legal changes that now facilitate the employment of non-EU graduates of Romanian universities. It will try to explore the extent to which the law is already implemented, the way in which it has been internalized and used by universities to communicate to non-EU students or in their student recruitment activities, but also to look at how inter-institutional cooperation functions in light of recent legal changes. The paper is exploratory in nature and tracks the implementation of Romania's new immigration legislation at a very early stage, just a year from the time of adoption. Nevertheless, from a policy analysis perspective, this is useful in order to identify weak spots on the road between legislative decisions and institutional practices.

R. Santa $(\varangle)$

National University of Political Studies and Public Administration, Bucharest, Romania

e-mail: robi.santa@gmail.com

C. M. Haj

Executive Agency for Higher Education, Research, Development and Innovation Funding,

Bucharest, Romania

e-mail: cezarhaj@gmail.com

(C) The Author(s) 2020

A. Curaj et al. (eds.), European Higher Education Area: Challenges for a New Decade, https://doi.org/10.1007/978-3-030-56316-5_10 
Avoiding any major controversies, the Romanian Parliament discretely modified immigration legislation in $2018,{ }^{1}$ trying to overhaul high thresholds for access to permanent residency. Prior to this, becoming a permanent resident in Romania as a non-EU citizen was more difficult and blocked at several choking points. On the one hand, a higher minimum wage was regulated for foreigners, on the other, a fixed quota and stern enforcement of employment preference for EU citizens represented further obstacles, though the latter provision is still formally in place. Changes in the new legislation included a provision that enabled foreign graduates in Romanian universities to seek employment for up to nine months after graduation, as an alternative to the six months awarded for the resolution of administrative issues following studies. The legislation was spearheaded by the need to align Romanian legislation with the provisions of European Directive (EU) 2016/801. The purpose of the Directive is, in turn, to harmonise the conditions for admission and authorisation at EU level and foster mobility for students and researchers. The Directive governs the conditions for third-country nationals for admission and authorisation as a researcher (and family members), student, trainee or volunteer in the context of European volunteer service. $^{2}$

These new approaches are not unique to Romania and should be seen in light of similar policy adaptation across Europe. These changes address the need of many governments to compensate for the ageing population of various European countries, the need for fiscal sustainability and the desire to make immigration fiscally valuable.

\section{Background}

While the EU is trying to expand the share of persons aged 30-34 who have completed a form of tertiary education to $40 \%$, non-EU immigration in many countries weighs down such goals. With a few exceptions, notably the UK with its high share of educated migrants, European countries tend to have immigrant populations with low levels of education.

For example, according to Eurostat data, almost $35 \%$ of non-EU immigrants had at most lower secondary education (ISCED 0-2), double the rate among Europeans without a migrant background. The share of tertiary education graduates among migrants was lower than the rate for natives and EU immigrants. ${ }^{3}$ Tertiary level

\footnotetext{
${ }^{1}$ Law text (Romanian) available online at: https://lege5.ro/Gratuit/gmydqobqgeza/legea-nr247-2018-pentru-modificarea-si-completarea-unor-acte-normative-privind-regimul-strainilorin-romania.

${ }^{2}$ https://ind.nl/en/news/Pages/New-directive-improves-mobility-within-the-EU-for-researchersand-students-from--\%E2\%80\%98third-countries\%E2\%80\%99.aspx.

${ }^{3}$ Eurostat, retrieved in October 2019 and available at: https://ec.europa.eu/eurostat/web/productseurostat-news/-/DDN-20190523-1.
} 
attainment would be even lower in the post-Brexit EU27, as Britain (and indeed, Ireland) tended to be outliers via their attraction of a highly educated migrant population. $^{4}$

The education level of immigrants seems to have a cascading effect in society, impacting other metrics. For example, one can easily notice that Britain has a smaller gap between non-EU migrant employment rates and the respective rate for natives. ${ }^{5}$ Ireland is in a similar position. Also, the gap in PISA test scores between immigrant and non-immigrant students is lower in countries with a more educated migrant population. In the case of Europe, this again leads to smaller differences in the United Kingdom, ${ }^{6}$ though it should be noted that—despite having a large number of migrants with ISCED 0-2 education - countries such as Spain and Italy also display moderate differences in results based on migration background. Research has already identified the key role of immigration policies in shaping the success of immigrants and their children in educational settings (e.g. Entorf and Minoiu 2004).

All of these issues are, from a demographic standpoint, important for European countries. All EU members, sans exception, have below-replacement fertility levels and have had them for decades. This means that the eventual decline in the number of people working will have to be compensated either by raising the productivity of the dwindling domestic workforce (for example via greater automation), by immigration or (as is most likely) by a combination of both.

International students have become a target for increasingly generous 'waivers' offered upon graduation in order to look for employment. While Britain briefly reversed a pre-2012 policy on allowing students to seek employment, it has since reverted to it, offering graduates a generous two-year period to seek employment (Adams 2019). Sweden has also introduced similar policies in order to tackle shortages of skilled workers (The Local 2019). Such policies also exist in countries such as the Netherlands, Denmark, Germany and, indeed, Romania since 2018.

These policies have a fairly simple principle: they enable international students to try and apply for employment in the country they study after graduation. The host country, especially if it has not asked the students to pay for the full cost of their tuition, or if they study in a field that sees skills shortages, is directly interested to at least offer the graduates a chance to extend their stay. The host country solves several issues related to immigration and integration by selecting graduates from domestic universities. First of all, there is a head-start on integration, even though it has to be said that many contemporary programs are taught in a foreign language (usually English). Secondly, issues such as diploma recognition and sector-specific internship experience are often solved before employment. Lastly, when the point

\footnotetext{
${ }^{4}$ Eurostat, retrieved in October 2019 and available at: https://ec.europa.eu/eurostat/statisticsexplained/index.php?title=Migrant_integration_statistics_-_education\#Educational_attainment. ${ }^{5}$ Eurostat, retrieved in October 2019 and available at: https://ec.europa.eu/eurostat/statisticsexplained/index.php/Migrant_integration_statistics_\%E2\%80\%93_labour_market_indicators\# Employment_rates.

${ }^{6}$ OECD data for PISA 2015, retrieved in October 2019 and available at: https://www.oecdilibrary.org/education/pisa-2015-results-volume-i/immigrant-background-student-performanceand-students-attitudes-towards-science_9789264266490-11-en.
} 
of immigration is tertiary education, the state waives most prior integration costs (language tutoring, pre-tertiary education) and quickly starts receiving the net fiscal benefit of having one more highly skilled resident in the tax system.

All of these benefits contrast with the more problematic integration of children with an immigrant background in general. Dronkers and de Heus (2012), as well as Dronkers and van der Velden (2013) point to a complex web of factors that influence educational performance among immigrant children in general, with factors such as religion, country of origin and community structures playing a role in education outcomes. With immigrants arriving as international students, the point of entry already includes a fairly high barrier defined by previous academic success.

Still, this modus operandi has some limitations. Policies aimed at recruiting students as skilled workers have a different logic than points-based systems, such as those developed by Australia and Canada. Most European countries use neither explicit quotas nor formally quantified systems of grading the merit of individual applications for residency. ${ }^{7}$ Employment and immediate labour market needs seem to be key concerns for policy-makers, in line with prior European efforts of recruiting 'guest workers'. Immediate needs take priority over long-term concerns with integration, and this could be seen as reflective of the lack of cultural awareness of what being a 'country of immigration' entails.

Policies aimed at facilitating immigration by international graduates are already impacting the makeup of immigrant contingents that are awarded residency in some of the countries that use them. The Netherlands, for example, now receives a steady flow of Indian immigrants, which often top annual non-EU, non-refugee immigration. ${ }^{8}$ Efforts to reduce immigration via family reunification that have preceded the recent international student boom mean that such inflows now dwarf immigration from previously dominant countries of origin (such as Morocco and Turkey). France has also seen its immigrants become increasingly educated, ${ }^{9}$ as have other countries inside the EU. The impact of the adoption of policies aimed at attracting a greater share of those highly skilled might be difficult to gauge for a while, especially when concerning indirect networked migration, ${ }^{10}$ as the 2015 refugee crisis has seen a big inflow of migrants that were not screened before arrival in Europe. That means that the overall sociodemographic profile of the total immigrant population might not improve in the short term.

While Romania has been-until recently-aloof of these efforts, the debate around attracting international students has intensified. After 2009, the number of students fell abruptly, especially in the private sector and in the fee-paying subsector in public universities (CNFIS 2014). At the same time, the one chronic problem of

\footnotetext{
${ }^{7}$ Exceptions do exist, such as the recent UK proposal on using a points-based system to assess immigration decisions after 2021.

${ }^{8}$ Dutch Statistics CBS, retrieved in October 2019 from: https://www.cbs.nl/en-gb/news/2019/30/ indian-knowledge-migration-has-doubled.

${ }^{9}$ French Statistics INSEE, retrieved in October 2019 from: https://www.insee.fr/fr/statistiques/ 3640742\#titre-bloc-6.

${ }^{10}$ For example, family reunification.
} 
unemployment and underemployment began gradually being reversed, with unemployment being as low as 3.9\% in September $2019,{ }^{11}$ below the EU average. Shortages in high-skills sectors could be potentially problematic in any national effort to completely close the middle-income trap. Romania is in a very poor position, as Eurostat places it in the very last spot when it comes to tertiary education attainment. Less than 25\% of people aged 30-34 have a higher education diploma as of 2018, and the number has even declined year-on-year. ${ }^{12}$ Romania is thus one of the few EU countries that risk failing to meet their Europe 2020 targets for tertiary education attainment.

In these conditions, Romania is at a tipping point in its need to attract a greater number of highly skilled graduates. It displays a mix of demographic contraction, low share of highly educated people among its own citizenry, rapid economic and wage growth and low unemployment. Legal efforts to facilitate highly skilled immigration now exist, and the ensuing trickle-down effect has now been set in motion by defining a legislative framework, though it is yet to be seen whether and how it will be used.

\section{Methodology}

The present paper used a three-fold approach in analysing the relevant topic. On the one hand, it analysed the legislative tools that govern education-centred immigration policies in both greater Europe and in Romania. This was necessary to frame recent legislative changes in Romania into what is a wider policy practice in Europe. The second tool was a brief desk research covering materials and articles related to internationalization efforts, including the argumentation used for the adoption of current legislation. The third tool was the use of interviews with key institutional representatives in Romania, to see the degree to which policy changes have been internalized by universities and are being used as part of Romania's offer to international students.

Of these instruments, semi-structured interviews were arguably the most important given that the paper tackles a very recent issue that has not yet been documented in academic literature or even in statistics bulletins. Due to some difficulties in establishing interviews with central authorities, the first four interviews were taken with representatives of universities that were deemed representative for the scope of this paper. These included three public and one private university. Three of the universities were based in Bucharest, while one was regional. The fifth interview was with central level representatives of the authority responsible with immigration, while a sixth was taken with the representative of a human resources company. The interviews, with two exceptions, were either with two persons or included follow-up

\footnotetext{
${ }^{11}$ Eurostat, retrieved in October 2019 and available at: https://ec.europa.eu/eurostat/statisticsexplained/index.php/Unemployment_statistics\#Recent_developments.

${ }^{12}$ Eurostat, retrieved in October 2019 and available at: https://ec.europa.eu/eurostat/statisticsexplained/index.php/Europe_2020_indicators_-_education\#Increasing_attainment_at_tertiary_ level.
} 
phone calls. This was due to the need, in bigger universities, to ask questions from both persons involved in decision-making and staff involved with the practical and administrative side of managing admission for international students. Thus, in total, 10 individuals were interviewed for this article.

It should be noted that some criteria were used in selecting universities. These had to have a significant (by Romanian standards) number of international students. Medical universities were excluded as these have traditionally attracted international students due to factors such as cost, numerus clausus in the home country or the value of Romanian diplomas in the context of professional regulation. Similarly, the universities were screened to avoid those that have an overwhelmingly Moldovanorigin international student body, as linguistic ties and legal facilities mean that Moldovan students are not international stricto sensu.

\section{Internationalization in Romania}

Internationalization has been the object of attention for education and policy researchers over the past few years, while its importance in higher education discourse and political practice has been rising. As universities have seen fewer and fewer domestic students due to the poor quality of secondary education and due to demographic factors, internationalization has also presented a greater level of interest for universities.

Deca et al. (2015) noted that internationalization efforts in Romania started off in a largely ad hoc manner, with no national strategy and with many policy changes determined by the need to comply with Bologna Process requirements or policy requirements associated with EU accession. These included the adoption of the European Credit Transfer and Accumulation System (ECTS), the use of the diploma supplement and more participation in EU mobility programmes, but did not preclude the continuation of traditional partnerships such as those associated with Agence Universitaire de la Francophonie (AUF) membership (ibid.). They also point to several structural obstacles existing in the way of internationalization efforts, including poor data collection, the lack of a national strategy and limited use of institutional strategies.

These deficiencies are also visible when looking at existing statistics. Romania remains a fairly marginal destination for international students. This can, for example, be seen with European mobilities, with 2.5 times more Romanians leaving the country than other Europeans arriving to study in local universities (UEFISCDI 2018). But the number of international students who undertake their studies in Romania outside the field of medicine, and who do not benefit from ethno-preferential access is small.

There is no research with regard to the degree to which employability was a factor in determining existing students to choose Romania. Such research does however exist for more general international student populations. When Medina and Duffy (1998) defined five main directions for branding for universities seeking to promote themselves internationally, graduate career prospects were one of these directions. 
In their paper, graduate career prospects referred to employment prospects per se, expected income and employer attitudes towards said graduates. Rajika Bhandari (2018) noted that Indian and Chinese students (the main US intakes) reported concerns about employment opportunities, especially when enrolling at graduate level. 41 of university campus administrators in the United States had, in fact, reported that concerns over the limited number of H1B work visas (which offer temporary employment to skilled foreign nationals) were a factor in the decline in the number of international students applying to study in the country (ibid).

An earlier study by Binsardi and Ekwulugo (2003) found that immigration and admission procedures ranked second after educational standards/qualification recognition among motivations offered by international students who had chosen to attend universities in Britain. Employment was third, ahead of costs, culture and lifestyle. The impact of talent retention is, of course, quite positive for the countries of destination, which reap the rewards of having a greater number of graduates within their overall populations. Varghese (2008:24) noted that employment prospects for internationally mobile students are high and that while this premium is greater in developing countries (often the countries of origin), many do stay, giving as an example the large share of Chinese and Indian students in the US tech sector.

It should be noted that while employability and employment prospects are a potential hook for international students, they are not necessarily a key driver for internationalization efforts by institutions. Altbach and Knight (2006) do not list the provision of employment for national labour markets as an institutional objective for internationalization. Ultimately, universities themselves benefit from internationalization mainly while the students are present.

As stated above, data shows that progress in attracting international students remains limited. Despite increased efforts to promote Romania as an international student destination, the number of newly arriving international students has been rising slowly. Furthermore, once Moldovans (who, due to the common language, are an atypical group of international students) are taken out of the tally, we actually see the past few years witnessing a slight decline in the number of study visas issued to non-Moldovan non-EU citizens (Table 1).

Nevertheless, within the body of students awarded Romanian study visas, there has been some diversification. While Israeli, Tunisian, Iraqi and Nigerian students seem to have witnessed a steep decline in the past few years (the latter two nationalities with a steep drop between 2015 and 2016), there has been a steady rise in the number of 'other' students coming from non-traditional destinations. These have risen from $28.3 \%$ in 2015 to $36.5 \%$ in 2018 among non-Moldovan arrivals. Of the big traditional countries of origin for international students, Turkey has seen a significant rise in total arrivals. 
Table 1 International student admissions (source: IGI)

\begin{tabular}{l|l|l|l|l|l}
\hline Citizens of & 2015 & 2016 & 2017 & 2018 & Total \\
\hline Moldova & 1612 & 1720 & 1849 & 2202 & 7383 \\
\hline Israel & 655 & 692 & 641 & 479 & 2467 \\
\hline Turkey & 443 & 509 & 586 & 591 & 2129 \\
\hline Morocco & 255 & 260 & 277 & 256 & 1048 \\
\hline Tunisia & 355 & 234 & 200 & 173 & 962 \\
\hline Serbia & 215 & 256 & 201 & 196 & 868 \\
\hline Ukraine & 115 & 138 & 141 & 183 & 577 \\
\hline Iraq & 226 & 132 & 96 & 107 & 561 \\
\hline Syria & 126 & 96 & 113 & 112 & 447 \\
\hline Nigeria & 246 & 53 & 67 & 75 & 441 \\
\hline Other & 1039 & 1149 & 1175 & 1249 & 4612 \\
\hline Total-MD & 3675 & 3519 & 3497 & 3421 & 14112 \\
\hline Total & $\mathbf{5 2 8 7}$ & $\mathbf{5 2 3 9}$ & $\mathbf{5 3 4 6}$ & $\mathbf{5 6 2 3}$ & $\mathbf{2 1 4 9 5}$ \\
\hline
\end{tabular}

\section{Findings}

Our initial research effort looked at existing legal documents and the arguments that they used. The Law 237/2018 was a catch-all overhaul law for Romania's immigration and residency legislation, creating new immigration pathways, simplifying others, reducing the requirements necessary to employ non-EU staff and facilitating international mobility in research, education and au pair childcare work. These changes brought Romanian legislation in line with European practices, but the law itself went beyond the scope of European Directive (EU) 2016/801.

Among the new provisions introduced or perfected by the Law, the most meaningful from the standpoint of education include:

1. A definition was now provided for what an international student was (both tertiary and pre-tertiary). A similar definition was provided for international interns ("stagiar"). These definitions did not change de facto practices but enabled better alignment with EU and additional legislation;

2. The concept of educational project was introduced and used as a criterion in awarding certain types of visas;

3. Punitive clauses were introduced to limit access to residency in Romania for foreigners who had committed various crimes and misdemeanours, including criminal acts, breaches of migration and employment legislation in Romania and other EU states;

4. The criteria for being awarded an international study visa was updated (though in practice remained broadly similar to prior conditions);

5. Additional criteria linked to income and assurance were inserted, in order to both ensure that international students can afford their studies; 
6. Provisions were introduced to facilitate the international mobility of non-EU citizens studying in another EU country;

7. There was an overhaul of criteria used to award visas to non-EU researchers, and to ease intra-EU mobility for non-EU researchers;

8. Lastly, students graduating in Romanian universities were awarded the chance to stay for nine months to seek employment.

It should be noted, however, that Romanian legislation does limit the absolute number of visas issued across categories. As such, there is an absolute cap that is placed on the number of foreign workers, currently at around 30.000 persons per year (Interview 5). This additional legislation authorizes the government to regulate the cap on a year-by-year basis, though interviewees from the immigration authority noted that this cap is not set in stone, and the total number of new admissions can be extended.

The other restriction to the formally open legislation is the requirement for prioritization of Romanian and European Union citizens. This is common across most of Europe as part of anti-social-dumping regulations that aim to limit employers from recruiting foreign workers and limiting wages. Nevertheless, law 247/2018 also toned down existing restrictions. For example, it lowered minimum wage requirements for non-EU citizens. Romanian minimum wage is now sufficient to employ a non-EU foreigners while before 2018 the floor was higher. The changes in legislation are likely to have a more limited effect on tertiary graduates, as they usually have a higher level of income to begin with.

It should be noted that while the new legislation explicitly regulated seeking employment as a valid reason for a visa extension, graduates had been able to find employment under the previous law (Interviews 4, 5). Even though legislation did not explicitly permit seeking employment upon graduation, immigration officials noted that the six-month extension offered to students in order to finish graduation formalities were in some cases used for this purpose. Nevertheless, the pre-Law 247 immigration regimen was often restrictive. One university (Interview 2) complained that, in practice, students had been struggling with visa extensions should they need a deadline extension for final thesis projects.

Labour shortages seemed to be acknowledged by most interviewees as a societal reality that is likely to affect Romania's long-term development. And, in the informal setting of the interviews, the respondents often acknowledged the importance of universities in attracting highly skilled foreign workers in the context of the demographic crisis. Employing skilled foreign workers has indeed been a long-time demand by employers, who often complain about labour shortages and currently use corporate networks or foreign agencies to recruit non-EU labour (Interview 6). In fact, legislative and executive authorities had already been addressing this issue before the adoption of Law 247/2018. For example, the overall cap on foreign workers has been raised in the past few years consistently, and it is current policy to raise it should the demand for workers exceed supply (Interview 5). However, up until now, this cap has mostly been used for recruitment in the hospitality and construction industries (Interview 5, 6). 
However, none of the academic responders had resorted to using employment prospects as a hook or a prominent feature of their public discourse targeting potential international students. Universities would often tout the cost-effectiveness of their programmes (Interviews 1, 3), the lifestyle offered by living in a major European capital (Interview 2) or a mix between the two (Interview 4). Respondents usually seemed to consider membership of the European Union as a major selling point, as this would enable easy recognition of awarded degrees for employment purposes (elsewhere in the European Union).

This, of course, is not entirely unexpected given the recent nature of the topic of immigration in public discourse in Romania. And, while immigration has been limited for the most part and is broadly a very recent phenomenon, emigration of both graduates and non-graduates has been a massified trend which has resulted in over 3.500.000 Romanian citizens living in other European Union countries. Nevertheless, there has also been a sharp increase in the number of immigrants living in the country in recent years, though this in itself is still largely an effect of circular migration by Romanian citizens moving back-and-forth from/to EU countries and a small but rapidly rising contingent of foreigners.

As Eurostat data indicates (see Table 2) the highest share of foreign-born residents in Romania is given by countries with Romanian diasporas, either ethnic or migratory. This points to a fairly low level of authentically foreign permanent or long-duration immigration to the country and could be a factor in explaining why the idea of targeting non-nationals for employment purposes has yet to catch on. There is a rapidly growing number of non-nationals who are employed on a temporary basis, but these are not skills-selected but are awarded visas based on existing (and often short-term) needs in the labour market (Interviews 5, 6).

This non-familiarity with the very topic of immigration can also be seen in inter-institutional cooperation, and how respondents related to it. While Bucharest-

Table 2 Residents in Romania by country of birth (source: Eurostat)

\begin{tabular}{l|l|l|l|l|l}
\hline Country/year & 2013 & 2018 & Country/year & 2013 & 2018 \\
\hline Romania & $19,862,852$ & $19,013,651$ & Russia & 4,952 & 7,189 \\
\hline Moldova & 59,670 & 199,703 & Greece & 4,085 & 6,864 \\
\hline Italy & 22,486 & 62,914 & China & 2,978 & 5,473 \\
\hline Spain & 18,827 & 47,311 & USA & 2,360 & 4,888 \\
\hline Ukraine & 8,743 & 24,570 & Israel & 1,665 & 3,660 \\
\hline $\begin{array}{l}\text { United } \\
\text { Kingdom }\end{array}$ & 2,604 & 21,050 & Syria & 2,295 & 3,358 \\
\hline Germany & 3,759 & 20,168 & Belgium & 54 & 3,269 \\
\hline France & 3,780 & 15,867 & Ireland & 3,780 & 2,632 \\
\hline Bulgaria & 11,163 & 10,543 & Serbia & 1,529 & 2,465 \\
\hline Hungary & 5,795 & 8,648 & Austria & 121 & 2,084 \\
\hline Turkey & 5,057 & 7,901 & Iraq & 1,136 & 2,045 \\
\hline
\end{tabular}


based universities tended to appreciate their cooperation with immigration authorities (Interviews 2, 3, 4), they mainly valued its role in facilitating visas and informing students on their rights, status changes etc. The only regional university interviewed had a less fortunate track-record in cooperating with regional immigration authorities (Interview 1). This contrasted with the attitude of the responders from the immigration authority, which seemed to consider employment as a priority in awarding visas. It should be noted that respondents who became familiar with recent legal changes during the interview process expressed openness to using employment prospects as a bigger part of their marketing and branding efforts.

A major point of criticism within inter-institutional cooperation was the process of awarding first-time entry visas for students. Due to the timing of the Romanian admission process (just 2-3 months before courses commence), the tradition of summer holidays in embassies and the limited capacity in consular offices, many students arrived in Romania after course started, with universities reporting delays ranging from over a month (Interview 2) to as long as three (Interview 4). There were also reports of countries where the rate of rejected visa applications was high enough to discourage future applicants (Interview 4). Among other findings of the interviews, there seemed to be a trend towards simplifying bureaucratic processes (a decision is often communicated to students using scanned files as opposed to physical dossiers), as well as an effort to better accommodate international students during their stay. The needs of international students reported by the interviewees were diverse, ranging from the provision of foreign language administrative services to-in an extreme example_-protection from radicalization efforts. One university complained that accreditation processes are not conducive to the development of study programmes in foreign languages, placing significant burdens on universities that try to develop English or French language versions of their existing study offer (Interview 2).

\section{Conclusions}

Romanian authorities have, in recent years, simplified many of the immigrationrelated restrictions that previously made attracting international students more onerous than in many other European countries. This has included better alignment to European regulations, more leniency in processing admission dossiers and indeed greater leeway for international students graduating in Romania to stay and seek employment within the country.

Administrative bodies tasked with implementing legislation seem proactive in implementing legislation to the advantage of international students, though the recent nature of the current legal framework does not offer scope for a quantitative analysis based on the number of issued visas and variations by category. Nevertheless, most Bucharest-based respondents deemed central level institutions as being supportive in their efforts to attract international students. 
On the other hand, the intra-institutional dialogue still seemed problematic. Most universities did not seem entirely familiar with the impact of recent legislative changes but were overall keen to use them in the future in order to better market themselves abroad. However, other state bodies were less conducive to greater openness. The late timeline of admissions, as currently regulated by law, means that students are pressed to obtain visas in a very short amount of time. Bureaucratic burdens remain and are indicative of a lack of inter-institutional trust, with certain policy priorities not reflected in the operational practices of embassies, for example.

As a broad conclusion, it can be said that the updated legislative framework is, at the moment, limited in its overall impact on internationalization of Romanian higher education by the permanence of certain barriers. Chief among them is the scheduling of admissions and the limited capacity of overseas Romanian embassies to process dossiers in order to award visas, though domestic bureaucratic issues also exist. The present article should warrant a follow-up once statistics are compiled for the first few years in the implementation of Law 247/2018, in order to determine if a statistically significant rise in international graduates seeking employment in the country occurs.

From a chronological point of view, and going beyond the findings of this paper, the new reforms can be seen as a new waypoint on the road to aligning Romanian higher education policies to those found in much of the rest of Europe. This started with the adoption of most Bologna tools, greater levels of mobility and greater research cooperation, but policy alignment is now crossing the boundary between education and immigration legislation in line with recent European practice. However, the extensive transformation brought about by Bologna and European Union membership is still incomplete. As in many other countries, de facto practices in the higher education system are anchored as much in older and deep-rooted traditions as they are in newer policy initiatives.

\section{List of interviews}

\begin{tabular}{l|l}
\hline Interview & Responders \\
\hline Interview 1 & Public university. Conducted via phone in two stages. Two responders \\
\hline Interview 2 & Public university. Conducted face-to-face. Two responders \\
\hline Interview 3 & Private university. Conducted face-to-face. One responder \\
\hline Interview 4 & $\begin{array}{l}\text { Public university. Conducted face-to-face with phone follow-up. Two } \\
\text { responders }\end{array}$ \\
\hline Interview 5 & $\begin{array}{l}\text { Public authority dealing with immigration. Face-to-face interview with } \\
\text { two responders }\end{array}$ \\
\hline Interview 6 & Representative of human resources company. Telephone interview \\
\hline
\end{tabular}




\section{References}

Adams, R. (2019, September $10^{\text {th }}$ ). UK work visas for foreign graduates to be extended to two years, The Guardian. Retrieved from: https://www.theguardian.com/education

P. G. Altbach and J. Knight, (2006), The Internationalization of Higher Education: Motivations and Realities, The NEA 2006 Almanac of Higher Education pp. 27-36

A Binsardi, F. Ekwulugo, (2003), International marketing of British education: research on the students' perception and the UK market penetration

CNFIS - National Council for Higher Education Funding (2014). Raportul public annual: Starea finantării învămământului superior românesc si măsurile de optimizare ce se impun. Bucharest: CNFIS.

Deca L., E Egron-Polak, CR.Fit, (2015). Internationalisation of Higher Education in Romanian National and Institutional Contexts, p. 138, Springer

Dronkers, J. and de Heus, M. (2012) Immigrants' Children Scientific Performance in a Double Comparative Design: The Influence of Origin, Destination, and Community. Discussion Paper Series 13/12. Centre for Research and Analysis of Migration Department of Economics, University College London.

Dronkers, J. and van der Velden, R. (2013) Positive but also Negative Effects of Ethnic Diversity in Schools on Educational Performance? An Empirical Test Using PISA Data. In Windzio, M., Integration and Inequality in Educational Institutions. Dordrecht: Springer Science.

Entorf, H. and Minoiu, N. (2004). PISA Results: What a Difference Immigration Law Makes. Discussion Paper. IZA DP No. 1021. Bonn: Institute for the Study of Labor (IZA).

Medina, J. F. \& Duffy, M. F. (1998) Standardisation vs globalisation: a new perspective of brand strategies, Journal of Product and Brand Management, Vol. 7 No. 4, pp. 173-178.

Rajika Bhandari, (2018). Attracting and Retaining Global Talent: International Graduate Students in the United States, International Higher Education, no. 93

The Local (2019, Sept 23 $\left.{ }^{\text {rd }}\right)$. Student job-hunters to get to stay one year in Sweden after uni, The Local. Retrieved from: https://www.thelocal.se/

UEFISCDI, (2018) Public Policy Center, Internationalizarea învătământului superior. Policy brief. Bucuresti: UEFISCDI.

Varghese, N.V. (2008). Globalization of higher education and cross-border student mobility. Paris: International Institute for Educational Planning.

Open Access This chapter is licensed under the terms of the Creative Commons Attribution 4.0 International License (http://creativecommons.org/licenses/by/4.0/), which permits use, sharing, adaptation, distribution and reproduction in any medium or format, as long as you give appropriate credit to the original author(s) and the source, provide a link to the Creative Commons license and indicate if changes were made.

The images or other third party material in this chapter are included in the chapter's Creative Commons license, unless indicated otherwise in a credit line to the material. If material is not included in the chapter's Creative Commons license and your intended use is not permitted by statutory regulation or exceeds the permitted use, you will need to obtain permission directly from the copyright holder.

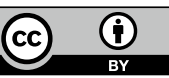

